\title{
The effect of combined polymorphisms in chemokines and chemokine receptors on the clinical course of HIV-1 infection in a Brazilian population
}

\author{
Valdimara Corrêa Vieira', Maria Fernanda Martínez Barral', Raul Andrés Mendoza-Sassi', \\ Jussara Maria Silveira' ${ }^{1}$ Marcelo Alves Soares ${ }^{2,3} /{ }^{+}$, Ana Maria Barral de Martínez ${ }^{1}$ \\ ${ }^{1}$ Faculdade de Medicina, Universidade Federal do Rio Grande, Rio Grande, RS, Brasil \\ ${ }^{2}$ Departamento de Genética, Centro de Ciências da Saúde, Universidade Federal do Rio de Janeiro, \\ Av. Brigadeiro Trompowski s/n Bl. A sala A2-120, 21949-570 Rio de Janeiro, RJ, Brasil \\ 3 Programa de Genética, Instituto Nacional de Câncer, Rio de Janeiro, RJ, Brasil
}

Polymorphisms in genes that encode chemokines or their receptors can modulate susceptibility to human immunodeficiency virus (HIV) infection and disease progression. The objective of this study was to assess the frequency of polymorphisms CCR5-432, CCR2-64I, CCR5-59029A and SDF1-3'A and their role in the course of HIV infection in a Southern Brazilian population. Clinical data were obtained from 249 patients for an average period of 6.4 years and genotypes were determined by standard polymerase chain reaction (PCR) and PCR-restriction fragment length polymorphism. Survival analyses were conducted for three outcomes: $C D 4^{+}$T-cell counts below 200 cells/ $\mu L$, acquired immune deficiency syndrome (AIDS) or death. The frequency of the polymorphisms CCR5- 332 , CCR264I, CCR5-59029A and SDF1-3'A were 0.024, 0.113, 0.487 and 0.207, respectively. CCR5- 332 was associated with a reduction in the risk for $\mathrm{CD}^{+}$T-cell depletion and with an increased risk for death after AIDS diagnosis. CCR2-64I was associated with a reduction in the risk for developing AIDS. SDF1-3'A was also associated with decreased risk for AIDS, but its effect was only evident when CCR2-64I was present as well. These results highlight the possibility of using these markers as indicators for the prognosis of disease progression and provide evidence for the importance of analysing the effects of gene polymorphisms in a combined fashion.

Key words: CCR5-A32 - CCR2-64I - CCR5-59029A - SDF1-3'A - HIV - disease progression

A significant portion of the variable clinical course profiles observed in the natural history of human immunodeficiency virus type 1 (HIV-1) infection is attributed to host genetic factors (Dean et al. 1996, Borghans et al. 2007, van Manen et al. 2008). Among these genetic factors are mutations found in genes encoding chemokines or their receptors (Dean et al. 1996, Quillent et al. 1998), which are key molecules in the HIV life cycle (Cocchi et al. 1995, Doranz et al. 1996, Dragic et al. 1996, Feng et al. 1996). One of the most notable effects on the clinical course of HIV infection is conferred by an internal 32 bp deletion $(\triangle 32)$ in the CCR5 chemokine receptor gene $(C C R 5-\triangle 32)$. This mutation leads to the synthesis of a truncated protein that fails to reach the cell surface (Liu et al. 1996). Homozygous individuals $(\Delta 32 / \Delta 32)$ are highly resistant to R5-tropic HIV-1 viruses (Dean et al. 1996, Samson et al. 1996). Heterozygous subjects $(+/ \Delta 32)$ are susceptible to infection but exhibit slower rates of progression to acquired immune deficiency syndrome (AIDS) when compared to wild-type homozygous counterparts (Dean et al. 1996, Liu et al. 1996, Samson et al. 1996).

Financial support: CNPq (471207/2008-0), FAPERJ (E-26/220.336/2007)

+Corresponding author: masoares@biologia.ufrj.br

Received 25 October 2010

Accepted 5 May 2011
The frequency of the CCR5- $\triangle 32$ allele varies in different ethnicities, occurring at a rate of $10-15 \%$ in Caucasians, $7 \%$ in Hispanics and $6 \%$ in African Americans, while it is virtually absent in native Africans and Asians (Samson et al. 1996, Williamson et al. 2000, Wang et al. 2003).

Polymorphisms in the promoter region of the CCR 5 gene, including a G/A polymorphism at position -59029 , have also been correlated with alterations in the clinical course of HIV infection (Martin et al. 1998, McDermott et al. 1998, An et al. 2000, Kaur et al. 2007). McDermott et al. (1998) showed that individuals homozygous for the $-59029 \mathrm{~A}$ variant progress faster to AIDS when compared to subjects homozygous for the $-59029 \mathrm{G}$ allele. The effect was stronger in the absence of the protective alleles CCR5- $\triangle 32$ and a non-synonymous amino acid polymorphism found at codon 64 of the CCR2 receptor gene (CCR2-64I). In the same study, it was also shown that the promoter region for the $-59029 \mathrm{G}$ allele displays $45 \%$ reduced activity compared to that of the $-59029 \mathrm{~A}$ variant in vitro. In a study conducted with both Caucasian and African-American patients, the -59029A allele was associated with a rapid progression to AIDS in both ethnicities. This phenotype was recessive in the former group and dominant in the latter (An et al. 2000). Both alleles are common, with the occurrence rate of -59029 A varying from $43-68 \%$, depending on ethnicity (McDermott et al. 1998). The effects of specific CCR5 haplotypes, consisting of polymorphisms in the CCR5/ $C C R 2$ promoter and coding regions, have also been reported. Particularly, the CCR5 HHE/HHE and $\mathrm{HHC} /$ 
$\mathrm{HHG}^{*} 2$ genotypes have been associated with, respectively, detrimental and beneficial effects in the course of HIV infection (Gonzales et al. 1999, Mangano et al. 2001, Nguyen et al. 2004, Casado et al. 2010, Catano et al. 2011). Polymorphisms in CCR5 as well as in other chemokine and chemokine receptor genes have also been associated with altered susceptibility to other infectious diseases, such as Chagas disease and hepatitis $\mathrm{C}$ (Hellier et al. 2003, Cunha-Neto et al. 2009).

A point mutation described in the gene encoding the CCR2 chemokine receptor also plays a role in HIV-1 pathogenesis. The polymorphism CCR2-64I represents a conservative change in the first transmembrane domain of the protein (Smith et al. 1997, Kostrikis et al. 1998), which does not alter its properties as a chemokine or HIV-1 receptor (Lee et al. 1998). Several studies have suggested a better prognosis for AIDS patients carrying the CCR2-64I variant (Smith et al. 1997, Kostrikis et al. 1998, Mulherin et al. 2003, Passam et al. 2005), but others have found contradictory results (Michael et al. 1997, Schinkel et al. 1999). Mummidi et al. (1998) showed a protective effect of this allele in African-Americans but not in Caucasians. Unlike the CCR5- 432 mutation, CCR2-64I was present in all ethnicities tested. CCR2-64I was observed at a frequency of $10 \%$ in Caucasians, $15 \%$ in African-Americans, $17 \%$ in Hispanics and 25\% in Asians (Smith et al. 1997, Williamson et al. 2000, Wang et al. 2003).

The polymorphism SDF1-3'A is characterised by a Gto-A transition in the 3'-UTR of the gene and was initially correlated with protection from HIV disease progression (Winkler et al. 1998). However, other studies did not find such a correlation (Ioannidis et al. 2001, Watanabe et al. 2003, Reiche et al. 2006), while a third group of studies found a correlation with accelerated disease progression (Mummidi et al. 1998, van Rij et al. 1998, Daar et al. 2005). SDF1-3'A distribution varies significantly between different populations, with frequencies from $2-9 \%$ in Africans and up to $54-71 \%$ in Oceania (Su et al. 1999).

CCR5- $432, C C R 2-64 I, C C R 5-59029 A$ and SDF1-3'A all exhibit variable frequencies in distinct populations (Smith et al. 1997, McDermott et al. 1998, Su et al. 1999, Gonzalez et al. 2001) and, possibly, their phenotypes depend on the ethnicity analysed (Mummidi et al. 1998, Gonzalez et al. 1999, 2001, An et al. 2000). The Brazilian population presents a complex genetic background, characterised by a high degree of miscegenation (Callegari-Jacques et al. 2003, Pena 2005). In major Brazilian cities, CCR5- $\triangle 32$ was found at frequencies of between 2-7\% (Munerato et al. 2003, Vargas et al. 2006, Reiche et al. 2008, Rigato et al. 2008), CCR5-59029A between $39-44 \%$ (Rigato et al. 2008), CCR2-64I at approximately $10 \%$ (Munerato et al. 2003, Rigato et al. 2008) and SDF1-3'A between 18-22\% (Reiche et al. 2006, Rigato et al. 2008). Despite the moderate rates of HIV infection reported in Brazil, little is known about the influence of genetic polymorphisms on HIV disease progression in this population. The aim of this study was to determine the frequency of the alleles CCR5- $432, C C R 2-64 I$, CCR5-59029A and SDF1-3'A and their combined influence on HIV disease progression in a cohort of HIV-infected patients from Southern Brazil.

\section{PATIENTS, MATERIALS AND METHODS}

Subjects and data collection - This was a retrospective longitudinal study. Two hundred and forty-nine $\mathrm{HIV}^{+}{ }^{+}$patients followed at the University Hospital of Universidade Federal do Rio Grande (HU-FURG) were recruited. Patients were followed for an average duration of 6.44 years. Clinical and laboratory data were obtained through medical chart review for the complete period between the diagnosis of HIV infection and the last follow-up visit until recruitment to the study. Baseline variables assessed were HIV plasma viral load, $\mathrm{CD}^{+} \mathrm{T}$ cell counts and clinical status. This study was approved by the Committee on Ethics in Institutional Research (CEPAS-FURG 23.116.002593/2007- 04).

Molecular analyses - Genomic DNA was extracted from patient whole blood samples using the GFX Genomic Blood Purification ${ }^{\mathrm{TM}}$ kit (Amersham Biosciences, Piscataway, NJ, USA). Genotyping of the CCR5 coding region ( $\mathrm{rs} 333$ ) was performed using polymerase chain reaction (PCR), while genotyping of CCR2 (rs1799864), the CCR5 promoter (rs1799987) and SDF1 (rs1801157) were performed using PCR followed by restriction fragment length polymorphism (PCR-RFLP). PCR reactions were conducted in a final volume of $25 \mu \mathrm{L}$ consisting of $5 \mathrm{pmol}$ of each primer, $0.3 \mathrm{mM}$ dNTP, $2.5 \mathrm{mM} \mathrm{MgCl}, 0.75 \mathrm{U}$ of Taq polymerase (Invitrogen Corporation, San Diego, CA), $20 \mathrm{mM}$ Tris- $\mathrm{HCl}$ $(\mathrm{pH}$ 8.4), $50 \mathrm{mM} \mathrm{KCl}$ and approximately $0.5 \mathrm{ug}$ of genomic DNA. For the $C C R 5$ coding region, the primers 5'CAAAAAGAAGGTCTTCATTACACC3' (forward) and 5'CCTGTGCCTCTTCTCATTTCG3' (reverse) were used as previously described (Huang et al. 1996). For the wild type allele, the amplified product was 189 bp long, while for the CCR5- $\triangle 32$ allele, it was $157 \mathrm{bp}$ long. PCR fragments were electrophoresed in a $2 \%$ agarose gel. For $C C R 2$ PCR amplification, the primers 5'GGATTGAACAAGGACGCATTTCCCC3' (forward) and 5'TTGCACATTGCATTCCCAAAGACCC3' (reverse) were used as described previously (Magierowska et al. 1999). The 380 bp products were subjected to RFLP with the restriction enzyme BseGI, generating two fragments (215 and $165 \mathrm{bp}$ ) only when the mutation corresponding to CCR2-64I was present. The wild type allele remained uncut (Suresh etal.2006). For the CCR 5 promoterregion, primers5'AAAATCCCCACTAAGATCCTG3' and 5'ATTCATCTAGTCAAAAGCCCAC3' were used (An et al. 2000). The final product of 394 bp was digested with $B s p 1286 \mathrm{I}$, generating two (329 and $65 \mathrm{bp}$ ) or three $(202,127$ and $65 \mathrm{bp})$ fragments for the alleles CCR 5-59029A or CCR5-59029G, respectively. Finally, for the amplification of $S D F-1$ gene, the primers 5'CAGTCAACCTGGGCAAAGCC-3' and 5'-CCTGAGAGTCCTTTTGCGGG-3' were used (Winkler et al. 1998). The 293 bp PCR product was subjected to RFLP with MspI. The digestion of the common $S D F-1$ allele produced two DNA fragments (100 and $193 \mathrm{bp}$ ), while the SDF1-3'A remained intact (Winkler et al. 1998).

Statistical analyses - The frequencies of the allele mutations were calculated and the Hardy-Weinberg equilibrium adequacy was tested with $X^{2}$. To evaluate the in- 
fluence of the polymorphisms on the course of infection, Cox proportional analyses [hazard ratios (HR) and their respective $95 \%$ confidence intervals] were conducted for three endpoints: (i) decline of $\mathrm{CD}^{+} \mathrm{T}$-cell counts to $<200$ cells $/ \mu \mathrm{L}$, (ii) progression to AIDS according the Brazilian national guidelines (presence of at least one opportunistic disease and/or CD4 $4^{+} \mathrm{T}$-cell counts $<350$ cells $/ \mu \mathrm{L}$ ) and (iii) time to death after AIDS diagnosis. The single effect of each polymorphism was evaluated with univariate Cox regression. Because baseline $\mathrm{CD} 4^{+}$ T-cell counts, baseline HIV viral load and age at HIV diagnosis could potentially act as confounding factors, multivariate analyses adjusted for these variables were performed for each polymorphism using Cox regression. A further multivariate analysis was conducted with the same model but included only patients undergoing antiretroviral therapy. The criterion for remaining in the model was a $p$ value $<0.05$.

In view of the small number of observed individuals homozygous for the alleles $C C R 2-64 I$ and $S D F 1-3$ ' $A$, their effect was verified by comparing heterozygous and rare homozygous with the respective common homozygous allele for each locus (CCR2-64I/+ and CCR2-64I/64I x CCR 2-+/+; SDF1-3'/+ and SDF1-3'A/3'A x SDF1-+/+). For $C C R 5-\triangle 32$, heterozygous individuals were compared with wild-type homozygous patients (CCR5- $432 /+\mathrm{x}$ $C C R 5-+/+$ ) because no CCR5- $\triangle 32 / \triangle 32$ patients were observed in the study. For CCR5-59029A, homozygotes for each allele (CCR5-59029A/A and CCR5-59029G/G) were compared with each other. Considering that the alleles CCR2-64I and CCR5-432 constitute confounding factors in measuring the effect of CCR5-59029A (McDermott et al. 1998), subjects harbouring any of those alleles were excluded from the analyses for this polymorphism. Finally, analyses of subjects with different combinations of polymorphisms were performed. A survival curve was constructed and the level of significance was determined through a log-rank test. Data were analysed in Stata v. 9.0. Differences were considered to be significant when $\mathrm{p}<0.05$ in two-sided tests.

\section{RESULTS}

Subject characteristics - Among the 249 patients included in the study, $163(65.5 \%)$ were female. At the first visit after diagnosis, the mean age was 31.2 years [confidence interval (CI) 14.1-65.8], the mean $\mathrm{CD}^{+}$ T-cell counts were 363 cells $/ \mu \mathrm{L}$ [ $\mathrm{n}=248$; standard deviation (SD) 277] and the average HIV viral load was 3.94 $\log _{10}$ copies $/ \mathrm{mL}(\mathrm{n}=236$; SD 2.48). At the beginning of follow-up, 117 (47\%) patients were asymptomatic, 39 $(15.7 \%)$ remained asymptomatic until the end of the study and $43(17.3 \%)$ patients died. The average time from diagnosis to progression to AIDS was 1.76 years (SD 2.69) and to death was 5.88 years (SD 3.07). During the followup, 193 patients $(83.9 \%)$ started antiretroviral therapy.

Polymorphism frequencies and their influence on HIV disease progression - The frequency of the polymorphisms studied is reported in Table I. No CCR5-432 homozygous subjects were observed. The genotypic frequencies observed were found to be in Hardy-Weinberg equilibrium (not shown).
TABLE I

Frequency of the various polymorphisms studied in human immunodeficiency virus type 1 (HIV-1) patients in Southern Brazil

\begin{tabular}{lcccc}
\hline & & \multicolumn{2}{c}{ Genotype frequency } & \\
\cline { 3 - 4 } Allele & $\mathrm{n}$ & $\begin{array}{c}\text { Heterozygous } \\
\mathrm{n}(\%)\end{array}$ & $\begin{array}{c}\text { Homozygous } \\
\mathrm{n}(\%)\end{array}$ & $\begin{array}{c}\text { Allele } \\
\text { frequency } \\
(\%)\end{array}$ \\
\hline CCR5-432 & 249 & $12(4.8)$ & $0(0)$ & 2.4 \\
CCR2-64I & 238 & $42(17.6)$ & $6(2.5)$ & 11.3 \\
CCR5-59029A & 235 & $115(48.9)$ & $57(24.3)$ & 48.7 \\
SDF1-3'A & 231 & $88(38.1)$ & $4(1.7)$ & 20.8 \\
\hline
\end{tabular}

The results of Cox proportional analyses are shown in Table II. An HR $>1$ or $<1$ indicates a greater or lower risk of progression to the outcome analysed, respectively. In the univariate analysis, the single effect of the four polymorphisms was investigated. For the $C C R 5$ coding region, the univariate analysis showed that individuals heterozygous for the allele (CCR5- $\triangle 32 /+)$ presented an $85 \%$ decreased risk of progression to $\mathrm{CD}^{+}$counts below 200 cells $/ \mu \mathrm{L}$ $(\mathrm{HR}=0.15, \mathrm{p}=0.04)$ (Table II). However, in the multivariate analysis, this protective effect was not significant (Table II). Considering death as endpoint, CCR5- $\triangle 32 /+$ individuals had a significantly increased risk in the multivariate analysis $(\mathrm{HR}=6.02, \mathrm{p}=0.004)$ (Table II).

To assess the effect of the CCR2-64I allele in the absence of $C C R 5-\triangle 32$, we excluded all individuals carrying the latter allele from our analyses. The univariate analyses showed that individuals carrying the CCR2-64I allele had a $35 \%$ reduced risk of progression to AIDS when compared to wild type homozygous subjects $(\mathrm{HR}=0.65, \mathrm{p}=$ 0.015 ) (Table II). The effect remained significant in the multivariate analysis $(\mathrm{HR}=0.7, \mathrm{p}=0.026)$ (Table II).

No significant correlation was detected between the polymorphism CCR5-59029A and the course of infection, even in the absence of the protective alleles CCR $5-\triangle 32$ and CCR2-64I (Table II). The SDF1-3'A allele also failed to show any association with changes in the HIV disease progression in our casuistic when analysed individually (Table II). We also performed an expectation-maximisation analysis of the polymorphisms clustered at chromosome 3 p21 and the results did not differ (Supplementary data).

We further analysed the effect of different allele combinations among those studied. Subjects were grouped in the following categories according to the $C C R 2$ and $S D F 1$ genotypes: (i) $S D F 1-+/+$ and $C C R 2-+/+(\mathrm{n}=109)$, (ii) $S D F 1-+/ 3 ' A$ or $S D F 1-3 ' A / 3 ' A$ and $C C R 2-+/+(\mathrm{n}=35)$, (iii) $S D F 1-+/+$ and CCR2-+/64I or CCR2-64I/64I $(\mathrm{n}=72)$ and (iv) $S D F 1-+/ 3 ' A$ or $S D F 1-33^{\prime} A / 3^{\prime} A$ and $C C R 2-+/ 64 I$ or CCR2-64I/64I $(\mathrm{n}=15)$. Cox regression analyses were conducted and the HR was determined when comparing category 1 (wild-type homozygous) with the remaining three categories. Subjects harbouring SDF1-3'A in the absence of CCR2-64I (category 2) had a 15\% reduction in the risk 
of progression to AIDS (HR $=0.85$, CI 0.65-1.1) (Table III), while subjects carrying CCR2-64I but not SDF1-3'A (category 3) had a $26 \%$ reduction in the risk for the same outcome $(\mathrm{HR}=0.74$, CI $0.5-1.11)$ (Table III). Subjects carrying both alleles had a $53 \%$ reduction in the risk of progression to AIDS (HR $=0.47$, CI 0.27-0.83, $\mathrm{p}=0.03$ ) (Table III). There was no significant correlation between these combined genotypes and decline of $\mathrm{CD}^{+}{ }^{+} \mathrm{T}$-cell counts below 200 cells $/ \mu \mathrm{L}$ or time to death (Table III).
Subjects harbouring at least one variant allele (CCR5$\triangle 32, C C R 2-64 I$ or $S D F 1-3{ }^{\prime} A ; \mathrm{n}=131$ ) displayed a significant reduction in the risk of progression to AIDS (HR = $0.71, p=0.03$ ) when compared to those with wild-type genotypes. Survival curves were constructed for both groups (Figure) and a significant difference was found $(\mathrm{p}=0.01, \log$-rank test). No difference between groups was found in the risk of the decline of $\mathrm{CD} 4^{+} \mathrm{T}$-cell counts to $<200$ cells $/ \mu \mathrm{L}$ or death.

TABLE II

Proportional Cox regression analyses of polymorphisms CCR5- $\triangle 32, C C R 2-64 I, C C R 5-59029 A$ and $S D F 1-3 ' A$ and the course of human immunodeficiency virus type 1 (HIV-1) infection

\begin{tabular}{|c|c|c|c|c|c|c|c|}
\hline \multirow[b]{2}{*}{ Allele } & \multirow[b]{2}{*}{$\mathrm{n}$} & \multicolumn{2}{|c|}{$\mathrm{CD} 4<200$ cells $/ \mu \mathrm{L}$} & \multicolumn{2}{|c|}{ AIDS $^{c}$} & \multicolumn{2}{|c|}{ Death $^{d}$} \\
\hline & & HR (CI) & $\mathrm{p}$ & HR (CI) & $\mathrm{p}$ & HR (CI) & $\mathrm{p}$ \\
\hline \multicolumn{8}{|l|}{ CCR5- $\triangle 32$} \\
\hline Univariate & 249 & $0.15(0.02-0.95)$ & 0.04 & $0.64(0.34-1.19)$ & 0.16 & $2.17(0.73-6.46)$ & 0.16 \\
\hline Multivariate $^{a}$ & 236 & $0.22(0.3-1.66)$ & 0.14 & $0.8(0.42-1.52)$ & 0.5 & $6.02(1.78-20.34)$ & 0.004 \\
\hline Multivariate $^{b}$ & 183 & $0.33(0.04-2.29)$ & 0.26 & $1.02(0.55-1.9)$ & 0.9 & $11.85(3.66-38.33)$ & 0.001 \\
\hline \multicolumn{8}{|l|}{ CCR2-64I } \\
\hline Univariate & 226 & $0.87(0.56-1.33)$ & 0.5 & $0.65(0.46-0.92)$ & 0.015 & $0.91(0.35-2.36)$ & 0.84 \\
\hline Multivariate $^{a}$ & 217 & $1.06(0.76-1.5)$ & 0.7 & $0.7(0.52-0.96)$ & 0.026 & $1.25(0.47-3.33)$ & 0.65 \\
\hline Multivariate $^{b}$ & 170 & $1.19(0.85-1.67)$ & 0.3 & $0.67(0.47-0.96)$ & 0.028 & $1.24(0.34-4.43)$ & 0.73 \\
\hline \multicolumn{8}{|l|}{ CCR5-59029A } \\
\hline Univariate & 95 & $1.07(0.65-1.78)$ & 0.77 & $0.88(0.62-1.27)$ & 0.5 & $0.14(0.02-1.09)$ & 0.06 \\
\hline Multivariate $^{a}$ & 89 & $1.05(0.5-1.71)$ & 0.83 & $0.9(0.65-1.24)$ & 0.53 & $0.16(0.02-1.06)$ & 0.12 \\
\hline Multivariate $^{b}$ & 75 & $1.08(0.66-1.18)$ & 0.74 & $0.95(0.7-1.31)$ & 0.77 & $0.24(0.02-2.4)$ & 0.22 \\
\hline \multicolumn{8}{|l|}{$S D F 1-3 ' A$} \\
\hline Univariate & 231 & $0.95(0.66-1.35)$ & 0.76 & $0.83(0.65-1.06)$ & 0.13 & $1.24(0.66-2.31)$ & 0.5 \\
\hline Multivariate $^{a}$ & 220 & $1.07(0.71-1.44)$ & 0.93 & $0.91(0.72-1.15)$ & 0.44 & $1.16(0.6-2.28)$ & 0.65 \\
\hline Multivariate $^{b}$ & 171 & $1.06(0.74-1.52)$ & 0.75 & $0.96(0.76-1.2)$ & 0.73 & $1.63(0.71-3.76)$ & 0.25 \\
\hline
\end{tabular}

$a$ : model adjusted for age at HIV diagnosis, baseline HIV viral load and baseline CD4 ${ }^{+}$T-cell counts; $b$ : model as in $a$, but restricted to patients under antiretroviral therapy; $c$ : according to the Brazilian Ministry of Health guidelines (MS 2003); $d$ : time to death after acquired immune deficiency syndrome (AIDS) diagnosis; CI: confidence interval; HR: hazard ratios.

TABLE III

Proportional Cox regression analysis of combinatorial SDF1-3'A and CCR2-64I genotypes in the course of human immunodeficiency virus type 1 (HIV-1) infection

\begin{tabular}{|c|c|c|c|c|c|c|c|}
\hline \multirow[b]{2}{*}{$S D F-1 / C C R 2$ genotype } & \multirow[b]{2}{*}{$\mathrm{n}$} & \multicolumn{2}{|c|}{$\mathrm{CD} 4<200$ cells $/ \mu \mathrm{L}$} & \multicolumn{2}{|l|}{$\operatorname{AIDS}^{a}$} & \multicolumn{2}{|l|}{ Death $^{b}$} \\
\hline & & $\mathrm{HR}(\mathrm{CI})$ & $\mathrm{p}^{c}$ & $\mathrm{HR}(\mathrm{CI})$ & $\mathrm{p}^{c}$ & $\mathrm{HR}(\mathrm{CI})$ & $\mathrm{p}^{c}$ \\
\hline$S D F 1=+/+$ and $C C R 2=+/+$ & 109 & 1 & 0.95 & 1 & 0.03 & 1 & 0.6 \\
\hline$S D F 1=3^{\prime} A /+$ or $3^{\prime} A / 3^{\prime} A$ and $C C R 2=+/+$ & 77 & $0.93(0.63-1.4)$ & - & $0.85(0.65-1.1)$ & - & $1.52(0.76-3.0)$ & - \\
\hline$S D F 1=+/+$ and $C C R 2=64 I /+$ or $64 I / 64 I$ & 30 & $0.88(0.5-1.6)$ & - & $0.74(0.5-1.11)$ & - & $1.41(0.45-4.4)$ & - \\
\hline$S D F 1=3^{\prime} A /+$ or $3^{\prime} A / 3^{\prime} A$ and $C C R 2=64 I /+$ or $64 I / 64 I$ & 15 & $0.87(0.46-1.65)$ & - & $0.47(0.27-0.83)$ & - & $0.68(0.09-5.12)$ & - \\
\hline
\end{tabular}

$a$ : according to the Brazilian Ministry of Health guidelines (MS 2003); $b$ : time to death after acquired immune deficiency syndrome (AIDS) diagnosis; $c$ : test of heterogeneity; CI: confidence interval; HR: hazard ratios. 


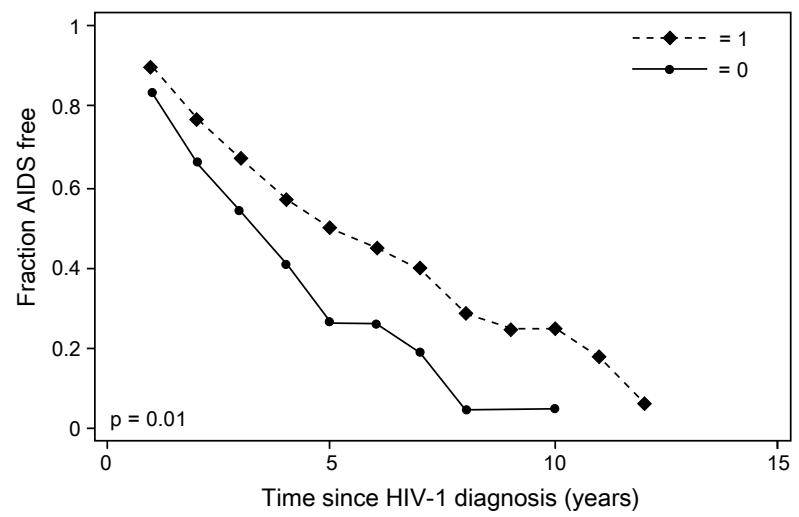

Survival curve showing the effect of the presence of one or more variant alleles (CCR5-432, CCR2-64I, CCR5-59029A or SDF1-3'A) on the time to progression to acquired immune deficiency syndrome (AIDS) in a Southern Brazilian cohort. p value was obtained through logrank test. HIV-1: human immunodeficiency virus type 1; 0: absence of polymorphisms; 1: presence of at least one polymorphism.

\section{DISCUSSION}

This study describes the genotype and allele frequencies of the polymorphisms CCR5- $\triangle 32, C C R 2-64 I$, CCR5-59029A and SDF1-3'A in an HIV-1-infected population from Southern Brazil. Most importantly, however, this study is the first to be conducted in Brazil that investigates the effects of such polymorphisms on the clinical course of HIV infection.

The polymorphisms analysed in this study exhibit variable frequencies in distinct populations (Smith et al. 1997, McDermott et al. 1998, Su et al. 1999, Gonzalez et al. 2001). As mentioned previously, the Brazilian population has a complex genetic background (CallegariJacques et al. 2003, Pena 2005). A study analysing different populations in Brazil showed the predominance of three mitochondrial lineages. The relative frequency of the lineages varied considerably among Brazilian regions. The majority of lineages from the North have Amerindian origin (54\%), whereas African ancestry is more common in the Northeast (44\%) and European is more common in the South $(66 \%)$. The South-eastern Region presented a balance between the frequencies of the three main lineages (Pena 2005). This genetic diversity plays an important role in the variable frequencies of these polymorphisms found within the country.

The CCR5- $\triangle 32$ allele has been found in Brazilian populations in frequencies between 2.2-6.8\% (Munerato et al. 2003, Vargas et al. 2006, Reiche et al. 2008, Rigatto et al. 2008). Here, we found a frequency of $2.4 \%$. Similarly, in another study conducted in Southern Brazil, the CCR5- $\triangle 32$ frequency was $2.9 \%$ among HIV-1 seropositive patients with AIDS, 5.6\% among those seropositive and asymptomatic, $5.6 \%$ in healthy blood donors and $5.51 \%$ in HIV-1-exposed seronegative subjects. CCR5-432 allelic frequencies were not different when the self-reported racial characteristics of the individuals evaluated were considered (Reiche et al. 2008). This allele has not been found among South American native
Indians, corroborating the hypothesis of a European origin of this allele and its introduction to the continent through migration (Leboute et al. 1999).

It is known that the distribution of the CCR2-64I mutation and its allelic frequency varies based on the population and ethnic groups studied (Martinson et al. 2000). Acosta et al. (2003) investigated the CCR2-64I mutation in three different Brazilian populations and found it at a frequency of $26 \%$ in Amerindians in the North, 30\% among German descendants in the South and 14\% in African descendants in the Northeast. In this study, we found the CCR2-64I allele to have a frequency of $11.3 \%$. Another study in the Southeast found an allele frequency of $8.15 \%$. These data are similar to those found in North America and Western Europe (Munerato et al. 2003).

The SDF1-3'A allele has a wide global prevalence. It has been found in high frequencies in Oceania and in lower frequencies in Africa (Su et al. 2000). In Brazil, Grimaldi et al. (2010), studying the same three populations that were analysed by Acosta et al. (2003) for CCR2$64 I$, found an allelic frequency of $21 \%$ in the population of the South, similar to the frequency found in this study $(20.1 \%)$. In the Northeast, the frequency was found to be $17 \%$ and, in the North, frequencies of $24 \%$ and $5 \%$ were observed in two different Amerindian tribes.

Finally, the CCR5-59029A allele has been found in frequencies above $40 \%$ in different populations (McDermott et al. 1998, O’Brien et al. 2000). In agreement with these results, the frequency found in this study was $48.7 \%$. Similarly, a study conducted in South-eastern Brazil found a frequency of $44.2 \%$ in HIV-infected individuals (Rigatto et al. 2008).

In our study, the univariate analysis showed that the presence of $C C R 5-\triangle 32$ conferred significant protection from the decline of $\mathrm{CD}^{+} \mathrm{T}$-cell counts below 200 cells/ $\mu \mathrm{L}$ in accordance to previous study (Eugen-Olsen et al. 1997). The slower progression observed in CCR5$\triangle 32$ heterozygous subjects could be attributed to the reduced cell surface expression of CCR5 (Wu et al. 1997), the main co-receptor for R5 strains of HIV-1, which predominate in the early stages of infection (Shankarappa et al. 1999).

The influence of the CCR5- $\triangle 32$ allele on the risk for $\mathrm{CD}^{+} \mathrm{T}$-cell count decline lost its significance when the model was adjusted for baseline HIV viral load, $\mathrm{CD}^{+}$ counts and age. This result suggests that, despite its protective effect, the CCR5- $\triangle 32$ genotype alone does not provide additional information on prognosis when other laboratorial markers are known, as suggested previously (Taylor et al. 2000). However, Kulkarni et al. (2008) showed that testing for possession of the CCR5- $\triangle 32$ allele in association with determining the copy number of CCL3L1, a potent CCR5 ligand, is predictive of disease progression independent of laboratory markers. This study illustrates how genomic information might be applied to achieve practical benefits (Kulkarni et al. 2008).

In contrast to the protective effect of the CCR5- $\triangle 32$ allele in the early stages of infection, we found the polymorphism to be correlated with an accelerated risk of death after AIDS diagnosis. This finding is congruent with data by Brumme et al. (2005), showing that indi- 
viduals heterozygous for $C C R 5-\triangle 32$ present a $2.5 \mathrm{X}$ increased risk of harbouring CXCR4-tropic HIV strains compared to homozygotes for the wild-type CCR5 allele. Considering that the emergence of X4 strains is usually associated with decreases in $\mathrm{CD} 4^{+} \mathrm{T}$-cell counts and with clinical progression (Connor et al. 1997), this emergence could explain the increased risk of progression to death in the late stages of infection found herein.

Several studies have suggested that the allele CCR5$59029 \mathrm{~A}$ is associated with an accelerated disease progression (McDermott et al. 1998, An et al. 2000, Kaur et al. 2007). In our study, such correlation was not evidenced. Martin et al. (1998) and An et al. (2000) suggested that the effect of this polymorphism is more evident in the first two-four years after seroconversion and subtler or even absent later on the infection. Because our study was conducted using chronically infected subjects, it is possible that this fact contributed to the lack of correlation observed.

In our study, individuals harbouring the CCR2-64I polymorphism showed a reduced risk for progression to AIDS. Nevertheless, as also reported by Kostrikis et al. (1998), the presence of this polymorphism did not alter the risk of $\mathrm{CD} 4^{+} \mathrm{T}$-cell decline. The mechanism by which CCR2-64I confers protection from disease progression remains unknown. The CCR2 receptor acts as a minor co-receptor for HIV-1 and the polymorphism CCR2-64I did not alter its properties as a chemokine receptor or as an HIV co-receptor (Lee et al. 1998). Some studies have suggested that this allele might diminish the expression of CCR5 and CXCR4 on the cell surface (Kostrikis et al. 1998, Mellado et al. 1999, Nakayama et al. 2004).

SDF1-3'A was also correlated with protection to disease progression in our study, but this effect was influenced by the $C C R 2$ genotype. SDF1-3'A-harbouring individuals were only protected in comparison to those carrying the wild-type form of both $S D F 1$ and $C C R 2$ genes. The considerable number of subjects harbouring CCR2-64I combined with the wild-type form of SDF1 (n $=30$ ) likely masked the protective effect of the $S D F 1-3$ 'A allele. However, subjects carrying both polymorphisms showed a $53 \%$ reduction in the risk of AIDS progression. This protection was higher than that observed in subjects carrying only one of those alleles, suggesting a cumulative effect. Our results highlight the need for analysing polymorphisms in genes that share a common molecular pathway in a conjoined manner.

The protective effect of the CCR5- $432, C C R 2-64 I$ and SDF1-3'A alleles was confirmed when comparing subjects carrying any of those polymorphisms to subjects who were homozygous for the wild-type form of all three genes. The reduction in risk for disease progression observed in individuals with these mutations provides evidence for the role of such polymorphisms and therefore the genetic background of the population, on HIV disease progression.

Some studies have investigated the role of polymorphisms in chemokine and chemokine receptor genes during the use of antiretroviral (ARV) therapy (O'Brien et al. 2000, Brumme et al. 2001, Passam et al. 2005). Our results showed that the use of ARV therapy did not influence the protective effects seen in the overall casuistic (Table II), as similar HR values were observed.
It is noteworthy to mention that the present study carries some important limitations. One of them is the reduced number of subjects included in the study, which may have masked some correlations among those analysed. Another limitation refers to the analysis of a chronically infected cohort, which may again mask some of the effects, as discussed above. However, a metaanalysis of the polymorphisms studied here has shown that similar results are obtained when analysing either recently or chronically-infected subjects (Ioannidis et al. 2001), suggesting that our results are relevant, particularly in this poorly studied population.

In summary, we demonstrated the protective effect of the CCR5- $432, C C R 2-64 I$ and SDF1-3'A alleles on the risk for AIDS progression in a Brazilian population. An important interaction between the alleles CCR2-64I and SDF1-3'A was observed. A temporal effect relative to the time of seroconversion was shown for the CCR5- $\triangle 32$ allele. Altogether, our results highlight the importance of studying genetic polymorphisms in different populations and their potential use as prognostic markers for HIV disease progression.

\section{REFERENCES}

Acosta AX, Sampaio RG, Spínola JL, Galvão-Castro B 2003. Distribution of the CCR2-64I allele in three Brazilian ethnic groups. Genet Mol Biol 26: 241-224.

An P, Martin MP, Nelson GW, Carrington M, Smith MW, Gong K, Vlahov D, O'Brien SJ, Winkler CA 2000. Influence of CCR5 promoter haplotypes on AIDS progression in African-Americans. AIDS 14: 2117-2122.

Borghans JA, Molgaard A, de Boer RJ, Kesmir C 2007. HLA alleles associated with slow progression to AIDS truly prefer to present HIV-1 p24. PLOS ONE 2: e920.

Brumme ZL, Chan KJ, Dong W, Hogg R, O’Shaughnessy MV, Montaner JSG, Harrigan PR 2001. CCR5-432 and promoter polymorphisms are not correlated with initial virological or immunological treatment response. AIDS 15: 2259-2266.

Brumme ZL, Goodrich J, Mayer HB, Brumme CJ, Henrick BM, Wynhoven B, Asselin JJ, Cheung PK, Hogg RS, Montaner JS, Harrigan PR 2005. Molecular and clinical epidemiology of CXCR4-using HIV-1 in a large population of antiretroviral naive individuals. J Infect Dis 192: 466-474.

Callegari-Jacques SM, Grattapaglia D, Salzano FM, Salamoni SP, Crossetti SG, Ferreira ME, Hutz MH 2003. Historical genetics: spatiotemporal analysis of the formation of the Brazilian population. Am J Hum Biol 15: 824-834.

Casado C, Colombo S, Rauch A, Martínez R, Günthard FH, Garcia S, Rodríguez C, Romero J, Telenti A, López-Galínde C 2010. Host and viral genetic correlates of clinical definitions of HIV-1 disease progression. PLoS ONE 5: e11079.

Catano G, Chykarenko ZA, Mangano A, Anaya JM, Weijing H, Smith A, Bologna R, Sen L, Clark RA, Lloyd A, Shostakovich-Koretskaya L, Ahuja SK 2011. Concordance of CCR5 genotypes that influence cell-mediated immunity and HIV-1 disease progression rates. $J$ Infect Dis 203: 263-272.

Cocchi F, DeVico AL, Garzino-Demo A, Arya SK, Gallo RC, Lusso P 1995. Identification of RANTES, MIP-1 alpha and MIP-1 beta as the major HIV-suppressive factors produced by $\mathrm{CD} 8^{+} \mathrm{T}$ cells. Science 270: 1811-1815.

Connor RI, Sheridan KE, Ceradini D, Choe S, Landau NR 1997. Change in coreceptor use correlates with disease progression in HIV-1-infected individuals. J Exp Med 85: 621-628. 
Cunha-Neto E, Nogueira LG, Teixeira PC, Ramasawmy R, Drigo SA, Goldberg AC, Fonseca SG, Bilate AM, Kalil J 2009. Immunological and non-immunological effects of cytokines and chemokines in the pathogenesis of chronic Chagas disease cardiomyopathy. Mem Inst Oswaldo Cruz 104 (Suppl. I): 252-258.

Daar ES, Lynn HS, Donfield SM, Lail A, O’Brien SJ, Huang W, Winkler CA, Hemophilia Growth and Development Study 2005. Stromal cell-derived factor-1 genotype, coreceptor tropism, and HIV type 1 disease progression. J Infect Dis 192: 1597-1605.

Dean M, Carrington M, Winkler C, Huttley GA, Smith MW, Allikmets R, Goedert JJ, Buchbinder SP, Vittinghoff E, Gomperts E, Donfield S, Vlahov D, Kaslow R, Saah A, Rinaldo C, Detels R, O'Brien SJ 1996. Genetic restriction of HIV-1 infection and progression to AIDS by a deletion allele of the CKR5 structural gene. Hemophilia Growth and Development Study, Multicenter AIDS Cohort Study, Multicenter Hemophilia Cohort Study, San Francisco City Cohort, ALIVE Study. Science 273: 1856-1862.

Doranz BJ, Rucker J, Yi Y, Smyth RJ, Samson M, Peiper SC, Parmentier M, Collman RG, Doms RW 1996. A dual-tropic primary HIV-1 isolate that uses fusin and the beta-chemokine receptors CKR-5, CKR-3 and CKR-2b as fusion cofactors. Cell 85: 11491158 .

Dragic T, Litwin V, Allaway GP, Martin SR, Huang Y, Nagashima KA, Cayanan C, Maddon PJ, Koup RA, Moore JP, Paxton WA 1996. HIV-1 entry into CD4 ${ }^{+}$cells is mediated by the chemokine receptor CC-CKR-5. Nature 381: 667-673.

Eugen-Olsen J, Iversen AK, Garred P, Koppelhus U, Pedersen C, Benfield TL, Sorensen AM, Katzenstein T, Dickmeiss E, Gerstoft J, Skinhøj P, Svejgaard A, Nielsen JO, Hofmann B 1997. Heterozygosity for a deletion in the CKR-5 gene leads to prolonged AIDS-free survival and slower CD4 T-cell decline in a cohort of HIV-seropositive individuals. AIDS 11: 305-310.

Feng Y, Broder CC, Kennedy PE, Berger EA 1996. HIV-1 entry cofactor: functional cDNA cloning of a seven-transmembrane, $G$ protein-coupled receptor. Science 272: 872-877.

Gonzalez E, Bamshad M, Sato N, Mummidi S, Dhanda R, Catano G, Cabrera S, McBride M, Cao XH, Merrill G, O’Connell P, Bowden DW, Freedman BI, Anderson SA, Walter EA, Evans JS, Stephan KT, Clark RA, Tyagi S, Ahuja SS, Dolan MJ, Ahuja SK 1999. Race-specific HIV-1 disease-modifying effects associated with CCR5 haplotypes. Proc Natl Acad Sci USA 96: 12004-12009.

Gonzalez E, Dhanda R, Bamshad M, Mummidi S, Geevarghese R, Catano G, Anderson SA, Walter EA, Stephan KT, Hammer MF, Mangano A, Sen L, Clark RA, Ahuja SS, Dolan MJ, Ahuja SK 2001. Global survey of genetic variation in CCR5, RANTES and MIP-1alpha: impact on the epidemiology of the HIV-1 pandemic. Proc Natl Acad Sci USA 98: 5199-5204.

Grimaldi R, Acosta AX, Machado TMB, Bomfim TF, Galvão-Castro B 2010. Distribution of SDF1-3'A polymorphisms in three different ethnic groups from Brazil. Braz J Infect Dis 14: 197-200.

Hellier S, Frodsham AJ, Hennig BJW, Klenerman P, Knapp S, Ramaley P, Satsangi J, Wright M, Zhang L, Thomas HC, Thursz M, Hill AVS 2003. Association of genetic variants of the chemokine receptor CCR5 and its ligands, RANTES and MCP-2, with outcome of HCV infection. Hepatology 38: 1468-1476.

Huang Y, Paxton WA, Wolinsky SM, Neumann AU, Zhang L, He T, Kang S, Ceradini D, Jin Z, Yazdanbakhsh K, Kunstman K, Erickson D, Dragon E, Landau NR, Phair J, Ho DD, Koup RA 1996. The role of a mutant CCR5 allele in HIV-1 transmission and disease progression. Nat Med 2: 1240-1243.

Ioannidis JP, Rosenberg PS, Goedert JJ, Goedert JJ, O’Brien TR, International Meta-analysis of HIV Host Genetics 2001. Effects of CCR5-Delta32, CCR2-64I, and SDF-1 3'A alleles on HIV-1 disease progression: an international meta-analysis of individualpatient data. Ann Intern Med 35: 782-795.
Kaur G, Singh P, Rapthap CC, Kumar N, Vajpayee M, Sharma SK, Wanchu A, Mehra NK 2007. Polymorphism in the CCR5 gene promoter and HIV-1 infection in north Indians. Hum Immunol 68: 454-461.

Kostrikis LG, Huang Y, Moore JP, Wolinsky SM, Zhang L, Guo Y, Deutsch L, Phair J, Neumann AU, Ho DD 1998. A chemokine receptor CCR 2 allele delays HIV-1 disease progression and is associated with a CCR5 promoter mutation. Nat Med 4: 350-353.

Kulkarni H, Agan BK, Marconi VC, O’Connell RJ, Camargo JF, He W, Delmar J, Phelps KR, Crawford G, Clark RA, Dolan MJ, Ahuja SK 2008. CCL3L1-CCR5 genotype improves the assessment of AIDS risk in HIV-1-infected individuals. PLOS ONE 3: e3165.

Leboute APM, Carvalho MWP, Simões AL 1999. Absence of the $\Delta \mathrm{ccr} 5$ mutation in indigenous populations of the Brazilian Amazon. Hum Genet 105: 442-443.

Lee B, Doranz BJ, Rana S, Yi Y, Mellado M, Frade JM, Martinez-A C, O’Brien SJ, Dean M, Collman RG, Doms RW 1998. Influence of the CCR2-V64I polymorphism on human immunodeficiency virus type 1 coreceptor activity and on chemokine receptor function of CCR2b, CCR3, CCR5, and CXCR4. J Virol 72: 7450-7458.

Liu R, Paxton WA, Choe S, Ceradini D, Martin SR, Horuk R, MacDonald ME, Stuhlmann H, Koup RA, Landau NR 1996. Homozygous defect in HIV-1 coreceptor accounts for resistance of some multiply-exposed individuals to HIV-1 infection. Cell 86 : 367-377.

Magierowska M, Theodorou I, Debre P, Sanson F, Autran B, Rivière Y, Charron D, Costagliola D 1999. Combined genotypes of CCR 5, CCR2, SDF1 and HLA genes can predict the long-term nonprogressor status in human immunodeficiency virus-1-infected individuals. Blood 93: 936-941.

Mangano A, Gonzalez E, Dhanda R, Catano G, Bamshad M, Bock A, Duggirala R, Williams K, Mummidi S, Clark RA, Ahuja SS, Dolan MJ, Bologna R, Sem L, Ahuja SK 2001. Concordance between the $\mathrm{CC}$ chemokine receptor 5 genetic determinants that alter risks of transmission and disease progression in children exposed perinatally to human immunodeficiency virus. $J$ Infect Dis 183: 1574-1585.

Martin MP, Dean M, Smith MW, Winkler C, Gerrard B, Michael NL, Lee B, Doms RW, Margolick J, Buchbinder S, Goedert JJ, O'Brien TR, Hilgartner MW, Vlahov D, O'Brien SJ, Carrington M 1998. Genetic acceleration of AIDS progression by a promoter variant of CCR5. Science 282: 1907-1911.

Martinson JJ, Hong L, Karanicolas R, Moore JP, Kostrikis LG 2000. Global distribution of the CCR2-64I/CCR5-59653T HIV-1 disease-protective haplotype. AIDS 14: 483-489.

McDermott DH, Zimmerman PA, Guignard F, Kleeberger CA, Leitman SF, Murphy PM 1998. CCR5 promoter polymorphism and HIV-1 disease progression. Multicenter AIDS Cohort Study (MACS). Lancet 352: 866-870.

Mellado M, Rodriguez-Frade JM, Vila-Coro AJ, de Ana AM, Martinez AC 1999. Chemokine control of HIV-1 infection. Nature 400: $723-724$.

Michael NL, Louie LG, Rohrbaugh AL, Schultz KA, Dayhoff DE, Wang CE, Sheppard HW 1997. The role of CCR5 and CCR2 polymorphisms in HIV-1 transmission and disease progression. Nat Med 3: 1160-1162.

MS - Ministério da Saúde/Brasil 2003. Critérios de definição de casos de AIDS em adultos e crianças (PN-DST/AIDS), MS, Brasília, 56 pp.

Mulherin SA, O’Brien TR, Ioannidis JP, Goedert JJ, Buchbinder SP, Coutinho RA, Jamieson BD, Meyer L, Michael NL, Pantaleo G, Rizzardi GP, Schuitemaker H, Sheppard HW, Theodorou ID, Vlahov D, Rosenberg PS, International Meta-Analysis of HIV Host Genetics 2003. Effects of CCR5-delta32 and CCR2-64I alleles on HIV-1 disease progression: the protection varies with duration of infection. AIDS 7: 377-387. 
Mummidi S, Ahuja SS, Gonzalez E, Anderson SA, Santiago EN, Stephan KT, Craig FE, O'Connell P, Tryon V, Clark RA, Dolan MJ, Ahuja SK 1998. Genealogy of the CCR5 locus and chemokine system gene variants associated with altered rates of HIV-1 disease progression. Nat Med 4: 786-793.

Munerato P, Azevedo ML, Sucupira MC, Pardini R, Pinto GH, Catroxo M, Souza IE, Diaz RS 2003. Frequency of polymorphisms of genes coding for HIV-1 co-receptors CCR 5 and CCR2 in a Brazilian population. Braz J Infect Dis 7: 236-240.

Nakayama EE, Tanaka Y, Nagai Y, Iwamoto A, Shioda T 2004. A CCR2-V64I polymorphism affects stability of CCR2A isoform. AIDS 18: 729-738.

Nguyen L, Li M, Chaowanachan T, Hu DJ, Vanichseni S, Mock PA, Griensven FV, Martin M, Sangkum U, Choopanya K, Tappero JW, Lal RB, Yang C 2004. CCR5 promoter human haplogroups associated with HIV-1 disease progression in Thai injection drug users. AIDS 18: 1327-1333.

O’Brien TR, McDermott DH, Ioannidis JP, Carrington M, Murphy PM, Havlir DV, Richman DD 2000. Effect of chemokine receptor gene polymorphisms on the response to potent antiretroviral therapy. AIDS 14: 821-826.

Passam AM, Zafiropoulos A, Miyakis S, Zagoreos I, Stavrianeas NG, Krambovitis E, Spandidos DA 2005. CCR2-64I and CXCL12 3'A alleles confer a favourable prognosis to AIDS patients undergoing HAART therapy. J Clin Virol 34: 302-309.

Pena SD 2005. Reasons for banishing the concept of race from Brazilian medicine. Hist Cienc Saude - Manguinhos 12: 321-346.

Quillent C, Oberlin E, Braun J, Rousset D, Gonzalez-Canali G, Métais P, Montagnier L, Virelizier JL, Arenzana-Seisdedos F, Beretta A 1998. HIV-1-resistance phenotype conferred by combination of two separate inherited mutations of CCR5 gene. Lancet 351: 14-18.

Reiche EM, Ehara Watanabe MA, Bonametti AM, Morimoto HK, Akira Morimoto A, Wiechmann SL, Matsuo T, Carvalho De Oliveira J, Vissoci Reiche F 2008. Frequency of CCR5-delta32 deletion in human immunodeficiency virus type 1 (HIV-1) in healthy blood donors, HIV-1-exposed seronegative and HIV-1seropositive individuals of Southern Brazilian population. Int J Mol Med 22: 669-675.

Reiche EM, Watanabe MA, Bonametti AM, Morimoto HK, Morimoto AA, Wiechmann SL, Matsuo T, Miranda HC, Reiche FV, Oliveira KB 2006. Stromal cell-derived factor 1 (SDF1) genetic polymorphism in a sample of healthy individuals, seronegative individuals exposed to human immunodeficiency virus type 1 (HIV-1) and patients infected with HIV-1 from the Brazilian population. Int J Immunogenet 33: 127-233.

Rigatto PO, Hong MA, Casseb J, Ueda M, de Castro I, Benard G, Duarte AJ 2008. Better CD4+ T cell recovery in Brazilian HIVinfected individuals under HAART due to cumulative carriage of SDF-1-3'A, CCR2-V64I, CCR5-D32 and CCR5-promoter 59029A/G polymorphisms. Curr HIV Res 6: 466-473.

Samson M, Libert F, Doranz BJ, Rucker J, Liesnard C, Farber CM, Saragosti S, Lapoumeroulie C, Cognaux J, Forceille C, Muyldermans G, Verhofstede C, Burtonboy G, Georges M, Imai T, Rana S, Yi Y, Smyth RJ, Collman RG, Doms RW, Vassart G, Parmentier M 1996. Resistance to HIV-1 infection in caucasian individuals bearing mutant alleles of the $C C R-5$ chemokine receptor gene. Nature 382: 722-725.

Schinkel J, Langendam MW, Coutinho RA, Krol A, Brouwer M, Schuitemaker H 1999. No evidence for an effect of the CCR5 delta32/+ and CCR2b 64I/+ mutations on human immunodeficiency virus (HIV)-1 disease progression among HIV-1-infected injecting drug users. J Infect Dis 179: 825-831.
Shankarappa R, Margolick JB, Gange SJ, Rodrigo AG, Upchurch D, Farzadegan H, Gupta P, Rinaldo CR, Learn GH, He X, Huang XL, Mullins JI 1999. Consistent viral evolutionary changes associated with the progression of human immunodeficiency virus type 1 infection. J Virol 73: 10489-10502.

Smith MW, Dean M, Carrington M, Winkler C, Huttley GA, Lomb DA, Goedert JJ, O’Brien TR, Jacobson LP, Kaslow R, Buchbinder S, Vittinghoff E, Vlahov D, Hoots K, Hilgartner MW, O'Brien SJ 1997. Contrasting genetic influence of CCR2 and CCR5 variants on HIV-1 infection and disease progression. Hemophilia Growth and Development Study (HGDS), Multicenter AIDS Cohort Study (MACS), Multicenter Hemophilia Cohort Study (MHCS), San Francisco City Cohort (SFCC), ALIVE Study. Science 277: 959-965.

Su B, Jin L, Hu F, Xiao J, Luo J, Lu D, Zhang W, Chu J, Du R, Geng Z, Qiu X, Xue J, Tan J, O’Brien SJ, Chakraborty R 1999. Distribution of two HIV-1 resistant polymorphisms (SDF1'A and CCR2$64 I$ ) in east Asia and world populations and its implication in AIDS epidemiology. Eur J Hum Genet 65: 1047-1053.

Su B, Sun G, Lu D, Xiao J, Hu F, Chakraborty R, Deka R, Jin L 2000. Distribution of three HIV-1 resistance-conferring polymorphisms (SDF1-3'A, CCR2-64I and CCR5-432) in global populations. Eur J Hum Genet 8: 975-979.

Suresh P, Wanchu A, Sachdeva RK, Bhatnagar A 2006. Gene polymorphisms in CCR5, CCR2, CX3CR1, SDF-1 and RANTES in exposed but uninfected partners of HIV-1 infected individuals in North India. J Clin Immunol 26: 476-484.

Taylor JMG, Wang Y, Ahdieh L, Chmiel J, Detels R, Giorgi J, Kaslow R, Kingsley L, Margolick J 2000. Causal pathways for CCR5 genotype and HIV progression. J Acquir Immune Defic Syndr 23: 160-171.

van Manen D, Rits MA, Beugeling C, van Dort K, Schuitemaker H, Kootstra NA 2008. The effect of Trim5 polymorphisms on the clinical course of HIV-1 infection. PLoS Pathog 4: e18.

van Rij RP, Broersen S, Goudsmit J, Coutinho RA, Schuitemaker H 1998. The role of stromal cell-derived factor-1 chemokine gene variant in the clinical course of HIV-1 infection. AIDS 12: 85-90.

Vargas AE, Marrero AR, Salzano FM, Bortolini MC, Chies JA 2006. Frequency of CCR5 delta 32 in Brazilian populations. Braz J Med Biol Res 39: 321-325.

Wang FS, Hong WG, Cao Y, Liu MX, Jin L, Hu LP, Wang Z, Feng TJ, Hou J, Zhang B, Shi M, Xu DP, Lei ZY, Wang B, Liu ZD, Ye JJ, Peng L, Qiu Y, Winkler C 2003. Population survey of CCR5 delta32, CCR $5 \mathrm{~m} 303, C C R 2 b 64 I$ and SDF1 3'A allele frequencies in indigenous Chinese healthy individuals and in HIV-1-infected and HIV-1-uninfected individuals in HIV-1 risk groups. $J$ Acquir Immune Defic Syndr 32: 124-130.

Watanabe MAE, Cavassin GGO, Orellana MD, Orellana MD, Milanezi CM, Voltarelli JC, Kashima S, Covas DT 2003. SDF-1 gene polymorphisms and syncytia induction in Brazilian HIV-1 infected individuals. Microb Pathog 35: 31-34.

Williamson C, Loubser SA, Brice B, Joubert G, Smit T, Thomas R, Visagie M, Cooper M, van der Ryst E 2000. Allelic frequencies of host genetic variants influencing susceptibility to HIV-1 infection and disease in South African populations. AIDS 14: 449-451.

Winkler C, Modi W, Smith M, Nelson GW, Wu X, Carrington M, Dean M, Honjo T, Tashiro K, Yabe D, Buchbinder S, Vittinghoff E, Goedert JJ, O'Brien TR, Jacobson LP, Detels R, Donfield S, Willoughby A, Gomperts E, Vlahov D, Phair J, O’Brien SJ 1998. Genetic restriction of AIDS pathogenesis by an $S D F-1$ chemokine gene variant. Science 279: 389-393.

Wu L, Paxton WA, Kassam N, Ruffing N, Rottman JB, Sullivan N, Choe H, Dosroski J, Newman W, Koup RA, Mackay CR 1997. CCR5 levels and expression pattern correlate with infectability by macrophage-tropic HIV-1 in vitro. J Exp Med 185: 1681-1691. 


\section{TABLE}

Distribution of haplotypes comprising the polymorphisms analyzed in genes clustered at 3p21 by outcomes

\begin{tabular}{|c|c|c|c|c|c|}
\hline \multirow[b]{2}{*}{ Outcome } & \multicolumn{4}{|c|}{ Haplotype (CCR2-64I/CCR5-59029A/CCR5- $\triangle 32)$} & \multirow[b]{2}{*}{$\mathrm{p}^{a}$} \\
\hline & $\begin{array}{c}C C R 2+/ C C R 5- \\
59029 G / C C R 5+ \\
\text { n }(\%)\end{array}$ & $\begin{array}{c}C C R 2+/ C C R 5- \\
59029 A / C C R 5+ \\
\mathrm{n}(\%)\end{array}$ & $\begin{array}{c}\text { CCR2-64I/CCR5- } \\
59029 A / C C R 5+ \\
\mathrm{n}(\%)\end{array}$ & $\begin{array}{c}C C R 2+/ C C R 5- \\
59029 A / C C R 5-\triangle 32 \\
\mathrm{n}(\%)\end{array}$ & \\
\hline \multicolumn{6}{|c|}{ CD4 $<200$} \\
\hline No & $98(0.21)$ & $113(0.24)$ & $31(0.06)$ & $10(0.02)$ & 0.3 \\
\hline Yes & $83(0.18)$ & $109(0.23)$ & $23(0.05)$ & $1(0.002)$ & - \\
\hline \multicolumn{6}{|l|}{ AIDS } \\
\hline No & $27(0.06)$ & $31(0.07)$ & $13(0.03)$ & $3(0.006)$ & 0.76 \\
\hline Yes & $154(0.3)$ & $191(0.4)$ & $41(0.09)$ & $8(0.02)$ & - \\
\hline \multicolumn{6}{|l|}{ Death } \\
\hline Yes & $149(0.31)$ & $189(0.4)$ & $47(0.1)$ & $9(0.02)$ & 0.9 \\
\hline No & $32(0.07)$ & $33(0.07)$ & $7(0.01)$ & $2(0.004)$ & - \\
\hline
\end{tabular}

$a$ : likelihood ratio test; AIDS: acquired immune deficiency syndrome. 